\title{
Morphological characteristics of Indonesian Rubus flowers
}

\author{
SULUH NORMASIWI ${ }^{1,2}$, ANDI SALAMAH ${ }^{3, \boldsymbol{v}}$, MUHAMMAD IMAM SURYA ${ }^{2}$ \\ ${ }^{1}$ Program of Conservation Biology, Department of Biology, Faculty of Mathematics and Natural Sciences, Universitas Indonesia. Jl. Prof. Sudjono D. \\ Pusponegoro, Kampus IU, Depok16424, West Java, Indonesia \\ ${ }^{2}$ Cibodas Botanical Garden, Research Center for Plant Conservation and Botanical Gardens, Indonesian Institute of Sciences. Jl. Kebun Raya Cibodas, \\ Sindanglaya, Cipanas, Cianjur 43253, West Java, Indonesia \\ ${ }^{3}$ Department of Biology, Faculty of Mathematics and Natural Sciences, Universitas Indonesia. Jl. Prof. Sudjono D. Pusponegoro, Kampus IU, \\ Depok16424, West Java, Indonesia. Tel.: +62-21-7270163, 78849009, Fax.: +61-21-78849010, ”email: salamah@ sci.ui.ac.id, snsuluhsiwi10@ gmail.com
}

Manuscript received: 18 January 2021. Revision accepted: 23 February 2021.

\begin{abstract}
Normasiwi S, Salamah A, Surya MI. 2021. Morphological characteristics of Indonesian Rubus flowers. Biodiversitas 22: 1441-1447. Rubus spp. are woody or herbaceous plants that can be used for fruit, ornamental and medicinal purposes. The increasing use of Rubus as a commercial species is highly dependent on the formation of high-quality genetic material. However, the lack of basic biological knowledge is one of the limiting factors in this development. This research aims to describe the morphological characters of Indonesian Rubus flowers at Cibodas Botanical Garden, Indonesian Institute of Sciences, Cianjur, West Java, Indonesia. From January to June 2020, we observed nine Rubus species with five replications, namely $R$. alceifolius, $R$. chrysophyllus, $R$. ellipticus, $R$. fraxinifolius, $R$. linneatus, $R$. moluccanus, $R$. pyrifolius, $R$. rosifolius, and Rubus sp (Blackberry) in Cibodas Botanical Garden, Indonesia. The results showed variations in the characteristics of the pistil, stamens, torus shape, and duration of flowering stages between species. The mean value of the stamen-pistil ratio for $R$. pyrifolius was highest among other species (8.27), and $R$. fraxinifolius was the lowest (0.16). Furthermore, a correlation analysis between stamens and pistils for nine Rubus species was relatively positive $(\mathrm{r}=$ 0.598 ), similarly distinctly positive between pistils and fruits with $r=0.763$. Flower development duration takes ranging $10-12$ days from initiation to anthesis, depending on the species.
\end{abstract}

Keywords: Anthesis, floral biology, Rubus, reproductive systems

\section{INTRODUCTION}

Plant reproductive systems and morphology have unique relations (Peng et al. 2014). Flowering plants have a different major in pattern sex expression depending on their form characteristics (Endress 2010; Williams 2012; Lu et al. 2015). Diversity species of flowering plants are generally indicated by the diversity of flowers and fruits, and species classification largely depends on flower and fruits idiosyncrasies (Redmond and Stout 2018; RamírezBarahona et al. 2020). The diversification of floral structure and function gives a convincing illustration in adaptive evolution and offers convenience for researching the functional association between floral traits and plant mating strategies.

Rubus (Rubus spp.), the genera that belong to Rosaceae, are woody or herbaceous plants with simple, pinnate, or palmate leaves. It is distributed in all continents except Antarctica on cultivable soils ranging from tropical to subarctic regions (Alice and Campbell 1999). In the tropics, Rubus are found in mountainous areas (Setyawan 1999). The prevalence of interspecific hybridization, polyploidy, and various forms of apomixis in Rubus, made it having a lousy reputation among taxonomists due to taxonomic classification became difficult (Kalkman 1993; Yang et al. 2015; Sochor et al. 2019; Lechowicz et al. 2020). In 1910, Focke grouped Rubus into twelve subgenera, namely Chamaemorus, Cylactis, Dalibarda, Chamaebatus, Comaropsis, Orobatus, Dalibardastrum,
Malachobatus, Anaplobatus, Idaeobatus, Lampobatus, and Rubus (Eubatus). Furthermore, Zandee and Kalkman (1981) note four subgenera distributed in Malesia, including Chamaebatus, Idaeobatus, Malachobatus, and Micranthobatus. Moreover, 46 Rubus species were recorded in the Malesia region, 25 spread in Indonesian mountain forests. In general, these genera display similar characters, such as having an inflorescence terminal in 5merous flowers, being mostly bisexual, rarely unisexual, and being dioecious, with numerous stamen and pistils on various type of torus. These plants most notable characteristic is their collective drupes fruit with or without the torus, rarely loose individually, with a juicy or fleshy mesocarp (Kalkman 1993).

Reproductive biology and flowering observations of some Rubus species (Raspberry, Blackberry) have been reported from America, North American, New Zealand, Norway, and Britain (Williams 1959; Heide and Sønsteby 2011; Nielsen et al. 2017; Hodnefjell et al. 2018; López et al. 2019). Most of these studies focused on single or commercials species. However, floral character morphology studies of wild Rubus are rare in South-east Asia, especially in Indonesia. Furthermore, the Indonesian Rubus flower's diversity has attracted little attention in the study of the functional association between floral traits and plant mating strategies. Cibodas Botanical Gardens (CBG), an ex-situ conservation institution located at the Cibodas Biosphere Reserve area, has thirteen wild species of Rubus as their garden collections. They namely Rubus 
acuminatissimus, Rubus alpestris, Rubus alceifolius, Rubus chrysophyllus, Rubus ellipticus, Rubus elongatus, Rubus fraxinifolius, Rubus lineatus, Rubus moluccanus, Rubus rosifolius, Rubus sumatranus, Rubus pyrifolius, and Rubus sp. Besides these species, CBG also has commercials Rubus cultivar such as blackberry and raspberry.

Susandarini (2016) and Moreno-Medina et al. (2018) reported that Rubus is one of the pioneers of forest succession and is potentially used for fruit, ornamental, and medicinal purposes. The development of Rubus as commercial species depends on the development of highquality genetic material. In-plant breeding program, the desired characteristics are obtained using existing variability, and the essential process for plant improvement is the understanding of pollination mechanisms (Frankel and Galun 2012; Sedgley and Griffin 2013). Furthermore, such material will require information on the species basic biology, which is currently lacking in some respect. This research aims to describe the morphological character of nine species of Indonesian Rubus flowers at Cibodas Botanical Garden. The information Rubus's floral morphology may add information on flower characters diversity for pollination knowledge and breeding systems.

\section{MATERIALS AND METHODS}

\section{Study species and site}

All observations and experiments were carried out at Cibodas Botanical Garden, Indonesian Institute of Sciences, Cianjur, West Java, Indonesia, from January to June 2020. CBG is located in the Cibodas Biosphere Reserve area with an altitude of 1200-1400 m a.s.l., an average temperature of $20^{\circ} \mathrm{C}$, and air humidity up to $96 \%$. Nine species Rubus spp. were investigated, consisting of eight wild species, $R$. alceifolius, $R$. chrysophyllus, $R$. ellipticus, $R$. fraxinifolius, $R$. linneatus, $R$. moluccanus, $R$. pyrifolius, $R$. rosifolius, and one commercial species, namely Rubus sp. (Blackberry).

\section{Flower development}

Observation of the nine Rubus species flowering stage was carried out at each stage of development, starting with a flower bud with a $1 \mathrm{~mm}$ diameter until one day before the flower anthesis. Then, the number of days needed for anthesis was also calculated.

\section{Flower morphology characters}

The variations in the flower morphology traits of Rubus spp were observed in the flower of nine species of Rubus, which were randomly selected with five replications. The flower's recorded characters were the number of pistils, the number of stamens, the stamen-pistil ratio, the number of fruits, and the inflorescence half flower at anthesis. Some additional characters were the color of the pistil and stamen, flower bud diameters one day before (D-1) anthesis, flower bud growth diameters, and the torus's size and shape at one day before (D-1) anthesis; the sepal and petal colors also observed. The number of pistils, stamens, and fruits were identified by the naked eye and counting manually. The size and form of flowers were measured by Microdirect 1080P HDMI Handheld digital microscope, then calculated with a mean value of five flowers per species. The torus's shape was divided into four categories: umbrella, triangular, parallel, and bulge. The Munsell plant tissue color chart measured the flower color. Then, the data were obtained, processed by the MS. Excel and IBM SPSS Statistics 21 software to get the mean value of size parts of flowers, stamens, pistils, and fruits number correlation within species analyzed by Rank Spearman correlation (two-tailed). Some data sets were transformed to a logarithmic scale before analysis to equalize variances. Fisher's Least Significance Different (LSD) 5\% was used as further statistic analysis when ANOVA shows significant differences and all the variable were analyzed by Principal Component Analysis (PCA)

\section{RESULTS AND DISCUSSION}

\section{Flower development}

The nine species of Rubus have different flower development (Figure 1). Time from flower initiation to anthesis (fully open flower) ranging from 10-12 days. Among the nine species of Rubus, the faster growth of flowering time is $R$. linneatus and $R$. chrysophyllus. Simultaneously, those that take longer to anthesis are $R$. alceifolius, $R$. ellipticus, $R$. fraxinifolius, and Rubus sp (Blackberry).

The appearance of half flower-cuts in Figure.2 illustrates a difference in length of pistils and stamens among the species and the torus variation shape. Anthers of those nine Rubus dehisced from outer to inner, which started at anthesis until D+3, and after D+3, anthers leak and dry out. Similarly, most stigmas were receptive at the anthesis stage. On the other hand, nine Rubus on observation produced nectar at the filaments' base as a reward.

\section{Flower morphology characters}

Comparing the number of pistils, stamen, and fruit of Rubus (Table 1) showed that $R$. rosifolius has the highest number of stamen and pistil among the species, with an average of 122 stamens and 404.6 number pistils. Meanwhile, $R$. linneatus had the lowest number of stamens with 42.67 , and $R$. pyrifolius had the lowest number of pistil with 6.6. The number of fruits from natural-pollinated among the species showed that $R$. fraxinifolius was the highest number of fruits with 340.00 (93\%), and the lowest was $R$. pyrifolius with $1.33(20 \%)$ fruits. Oppositely, the mean value of the stamen-pistil ratio for $R$. pyrifolius was highest among other species (8.27), and $R$. fraxinifolius was the fewest (0.16).

Additionally, the correlation analysis by Spearman rank (Table 2) between stamens and pistils for nine species of Rubus was relatively positive $(\mathrm{r}=0.598)$. Similarly, the correlation analysis between pistils and fruits distinctly positive with $\mathrm{r}=0.763$. On the other hand, between stamens and fruits was not any significant correlation. 


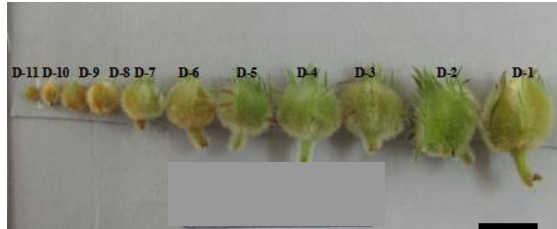

A

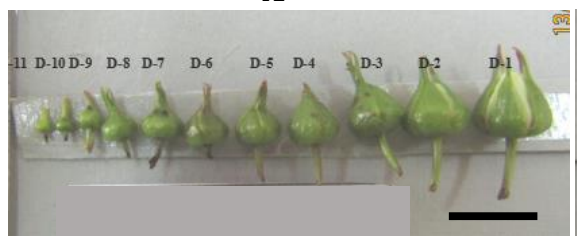

D

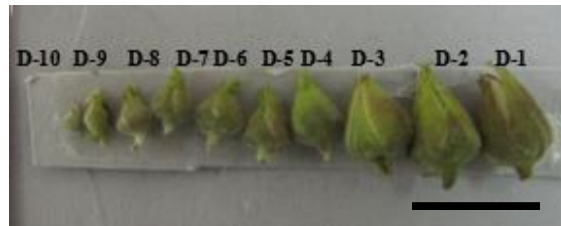

G

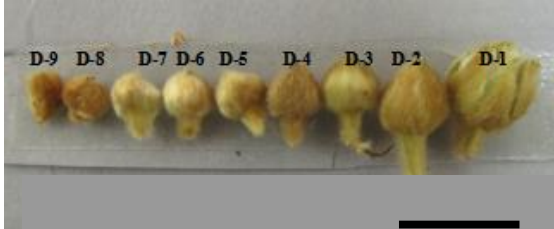

B

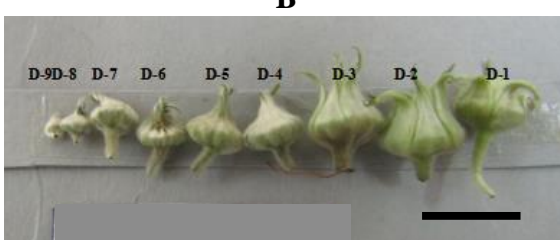

$\mathbf{E}$

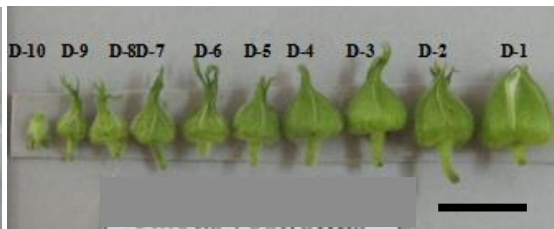

H

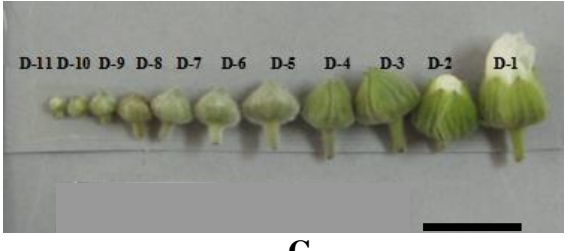

C

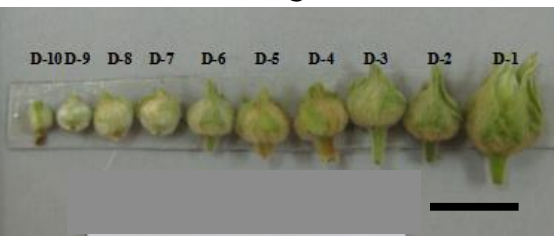

$\mathbf{F}$

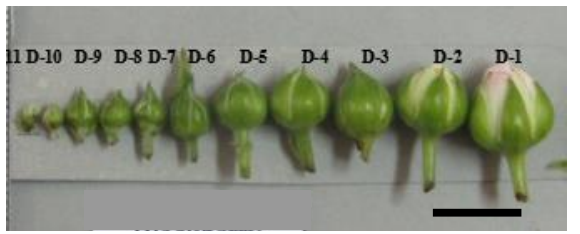

I

Figure 1. Flower development processes of nine Rubus species. A. R. alceifolius, B. R. chrysophyllus, C. R. ellipticus, D. R. fraxinifolius, E. R. lineatus, F. R. moluccanus, G. R. rosifolius, H. R. pyrifolius, I. Rubus sp. (blackberry). Scale bar $=1 \mathrm{~cm}$

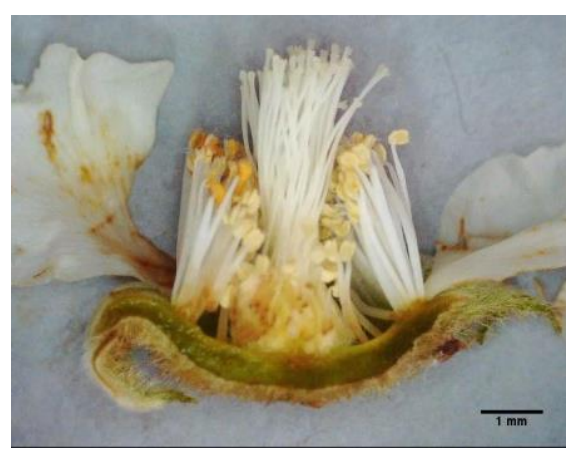

$\mathbf{A}$

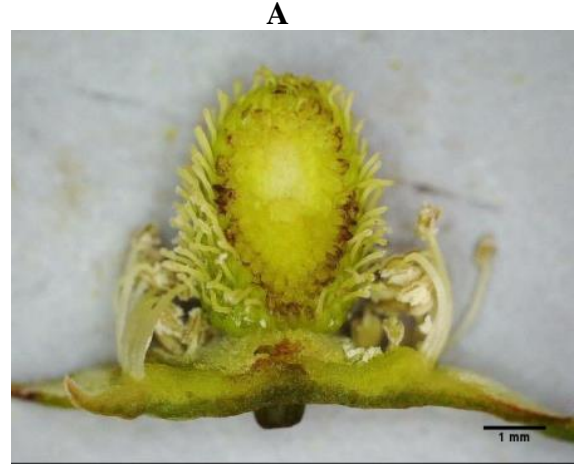

D

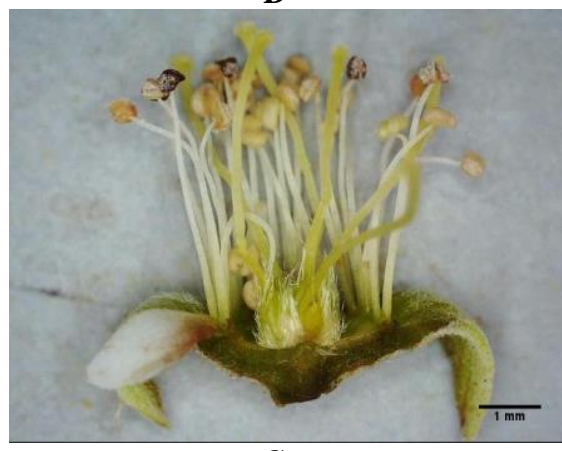

$\mathbf{G}$

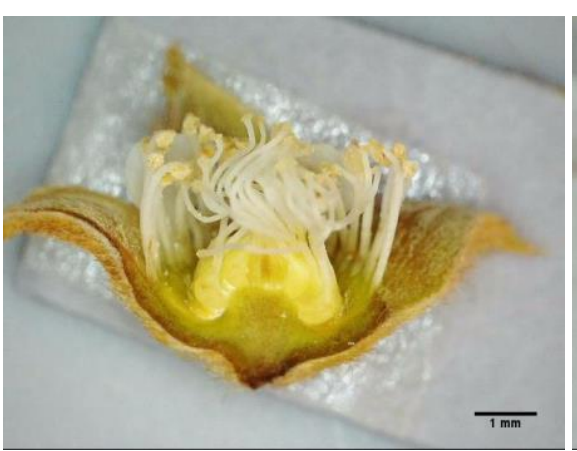

B

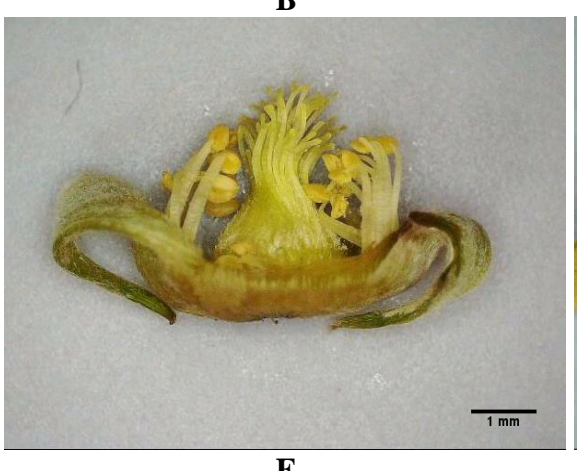

$\mathbf{E}$

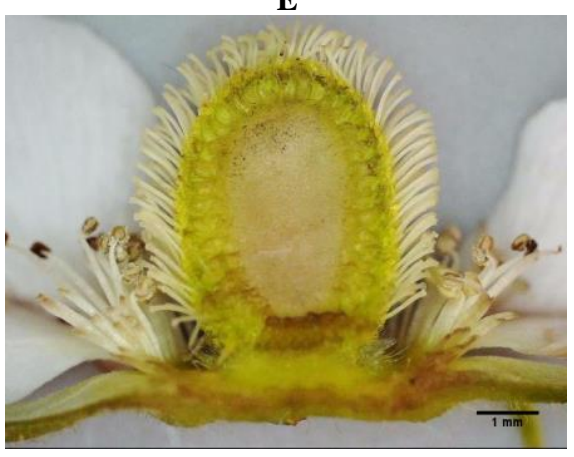

$\mathbf{H}$

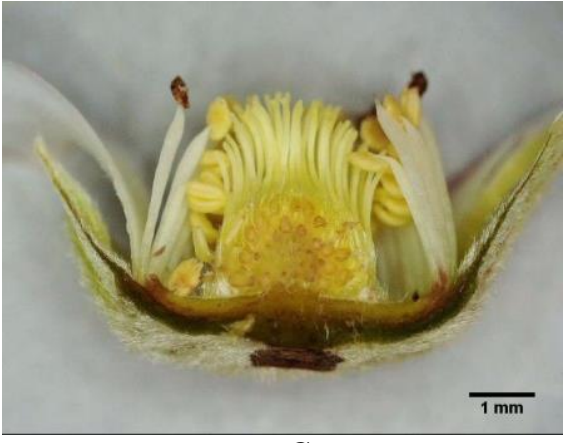

$\mathbf{C}$
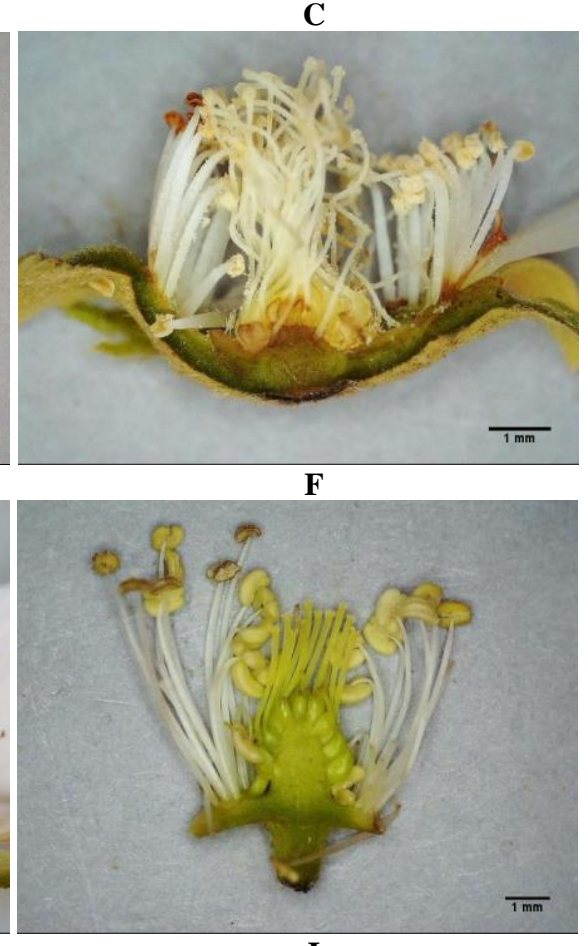

Figure 2. Half flower-cuts of nine species Rubus. A. R. alceifolius, B. R. chrysophyllus, C. $R$. ellipticus, D. R. fraxinifolius, E. $R$. lineatus, F. R. moluccanus, G. R. pyrifolius, H. R. rosifolius, I. Rubus sp. (blackberry). Scale bar $=1 \mathrm{~mm}$. One day old flower (D1) 
Table 1. The number of stamen, pistil, and fruit of nine species Rubus

\begin{tabular}{|c|c|c|c|c|}
\hline Species of Rubus & Number of stamens & Number of pistils & Stamen-pistil ratio & Number of fruits \\
\hline R. alceifolius & $95.20 \mathrm{~b}$ & $73.20 \mathrm{~d}$ & $1.30 \mathrm{bc}$ & $17.00 \mathrm{c}$ \\
\hline R. chrysophyllus & $56.25 \mathrm{~d}$ & $39.33 f$ & $1.99 \mathrm{~b}$ & $35.67 \mathrm{bc}$ \\
\hline R. ellipticus & $80.00 b c$ & $138.50 \mathrm{c}$ & $0.58 \mathrm{bc}$ & $58.33 b$ \\
\hline R. fraxinifolius & $61.60 \mathrm{~cd}$ & $365.33 b$ & $0.16 \mathrm{c}$ & $340.00 \mathrm{a}$ \\
\hline R. lineatus & $42.67 d$ & $67.33 \mathrm{de}$ & $0.65 b c$ & $36.67 \mathrm{bc}$ \\
\hline R. moluccanus & $95.20 \mathrm{~b}$ & $73.20 \mathrm{~d}$ & $1.30 \mathrm{bc}$ & $35.67 \mathrm{bc}$ \\
\hline R. pyrifolius & $53.60 d$ & $6.60 \mathrm{~g}$ & $8.27 \mathrm{a}$ & $1.33 \mathrm{~d}$ \\
\hline$R$. rosifolius & $122.00 \mathrm{a}$ & $404.60 \mathrm{a}$ & $0.30 \mathrm{c}$ & $292.00 \mathrm{a}$ \\
\hline Rubus sp. (Blackberry) & $64.00 \mathrm{~cd}$ & $49.00 \mathrm{e}$ & $1.33 \mathrm{bc}$ & $26.00 \mathrm{bc}$ \\
\hline
\end{tabular}

Note: The number followed by similar low case letters in the same column are not significantly different according to the LSD test at $5 \%$

Table 2. Spearman rank correlation coefficients number of stamen, pistils, and fruits for nine species of Rubus

\begin{tabular}{lccc}
\hline Correlation coefficient & Number of stamens & Number of pistils & Number of fruits \\
\hline Number of stamens & 1.00 & $0.598^{* *}$ & 0.218 \\
Number of pistils & $0.598^{* *}$ & 1.00 & $0.763^{* *}$ \\
Number of fruits & 0.218 & $0.763^{* *}$ & 1.00 \\
\hline$* *$ Corr
\end{tabular}

${ }^{* *}$ Correlation is significant at the 0.01 level

Table 3. Characteristics (length and color) stamen and pistil of nine species Rubus. The number followed by similar low case letters in the same column are not significantly different according to the LSD test at $5 \%$.

\begin{tabular}{lcccc}
\hline \multirow{2}{*}{ Species of Rubus } & \multicolumn{3}{c}{ Stamen } & Pistil \\
\cline { 2 - 5 } & Length $(\mathbf{m m})$ & \multicolumn{1}{c}{ Color } & Length $(\mathbf{m m})$ & Color \\
\hline R. alceifolius & $3.95 \mathrm{~b}$ & Light yellow-green & $7.32 \mathrm{a}$ & Grayish yellow-green \\
R. chrysophyllus & $2.23 \mathrm{de}$ & Pale yellow & $4.25 \mathrm{de}$ & Light yellow-green \\
R. ellipticus & $2.73 \mathrm{~cd}$ & Light yellow-green & $1.90 \mathrm{f}$ & Light yellow-green \\
$R$ fraxinifolius & $1.91 \mathrm{ef}$ & Pale yellow & $1.82 \mathrm{f}$ & Grayish yellow-green \\
$R$. lineatus & $1.35 \mathrm{f}$ & Strong yellow & $4.70 \mathrm{~cd}$ & Pale yellow \\
$R$. moluccanus & $3.01 \mathrm{c}$ & Pale yellow-green & $5.64 \mathrm{~b}$ & Light yellow-green \\
$R$. pyrifolius & $4.84 \mathrm{a}$ & Pale yellow & $5.12 \mathrm{bc}$ & Strong yellow-green \\
$R$. rosifolius & $2.52 \mathrm{cde}$ & Light yellow-green & $1.81 \mathrm{f}$ & Strong yellow-green \\
Rubus sp. (Blackberry) & $5.59 \mathrm{a}$ & Pale yellow & $3.95 \mathrm{e}$ & Grayish yellow-green \\
\hline
\end{tabular}

Table 4. Characteristic flower of nine species Rubus (mean \pm s.e). The number followed by similar low case letters in the same column are not significantly different according to the LSD test at $5 \%$

\begin{tabular}{lccclll}
\hline \multicolumn{1}{c}{ Species of Rubus } & $\begin{array}{c}\text { Flower bud } \\
\text { diameters D-1 } \\
(\mathbf{m m})\end{array}$ & $\begin{array}{c}\text { Flower bud } \\
\text { growth } \\
\text { diameters } \\
(\mathbf{m m} / \mathbf{d a y})\end{array}$ & $\begin{array}{c}\text { Tiameters } \\
(\mathbf{m m})\end{array}$ & Forms & Petal color & Sepal color \\
\hline R. alceifolius & $5.83 \mathrm{a} \pm 1.031$ & $0.41 \mathrm{a} \pm 0.035$ & $1.84 \mathrm{a} \pm 0.248$ & Umbrella & Grayish yellow-green & Strong yellow-green \\
R. chrysophyllus & $3.74 \mathrm{a} \pm 0.182$ & $0.42 \mathrm{a} \pm 0.063$ & $1.35 \mathrm{a} \pm 0.066$ & Triangular & Grayish yellow-green & Strong yellow-green \\
R.ellipticus & $3.71 \mathrm{a} \pm 0.283$ & $0.34 \mathrm{a} \pm 0.062$ & $0.93 \mathrm{a} \pm 0.071$ & Triangular & Pale yellow-green & Moderate yellow-green \\
R. fraxinifolius & $5.04 \mathrm{a} \pm 0.678$ & $0.43 \mathrm{a} \pm 0.361$ & $1.52 \mathrm{a} \pm 0.176$ & Bulge & Grayish yellow-green & Moderate yellow-green \\
R. lineatus & $5.05 \mathrm{a} \pm 0.551$ & $0.37 \mathrm{a} \pm 0.037$ & $1.60 \mathrm{a} \pm 0.140$ & Parallel & Grayish yellow-green & Moderate yellow-green \\
R. moluccanus & $4.32 \mathrm{a} \pm 0.342$ & $0.34 \mathrm{a} \pm 0.053$ & $2.40 \mathrm{a} \pm 1.185$ & Umbrella & Grayish yellow-green & Moderate yellow-green \\
R. pyrifolius & $3.51 \mathrm{a} \pm 0.105$ & $0.25 \mathrm{a} \pm 0.057$ & $0.99 \mathrm{a} \pm 0.119$ & Umbrella & Grayish yellow-green & Strong yellow-green \\
R. rosifolius & $5.11 \mathrm{a} \pm 0.439$ & $0.30 \mathrm{a} \pm 0.007$ & $1.85 \mathrm{a} \pm 0.184$ & Bulge & Grayish yellow-green & Strong yellow-green \\
Rubus sp (blackberry) & $5.81 \mathrm{a} \pm 0.132$ & $0.48 \mathrm{a} \pm 0.019$ & $1.22 \mathrm{a} \pm 0.557$ & Bulge & Grayish yellow-green & Strong yellow-green \\
\hline
\end{tabular}

Note: $* \mathrm{D}-1=$ one day before anthesis. ns $=$ not significant 
Table 5. Eigenvalue and percentage of variance values and factor loadings generated by PCA

\begin{tabular}{llll}
\hline & PC1 & PC2 & PC3 \\
\hline Eigenvalue & 2.980 & 1.658 & 1.449 \\
Variability (\%) & 37.254 & 20.728 & 18.109 \\
Cumulative (\%) & 37.254 & 57.982 & 76.092 \\
Number of pistils & 0.817 & 0.488 & -0.164 \\
Number of stamens & 0.297 & 0.784 & -0.31 \\
Number of fruits & 0.89 & 0.192 & 0.036 \\
Length of pistil & -0.884 & 0.163 & 0.053 \\
Length of stamen & -0.606 & 0.041 & -0.074 \\
Flower bud diameter & -0.01 & 0.503 & 0.755 \\
Flower bud growth diameter & 0.044 & -0.222 & 0.89 \\
Torus diameter & -0.116 & 0.789 & 0.187 \\
\hline
\end{tabular}

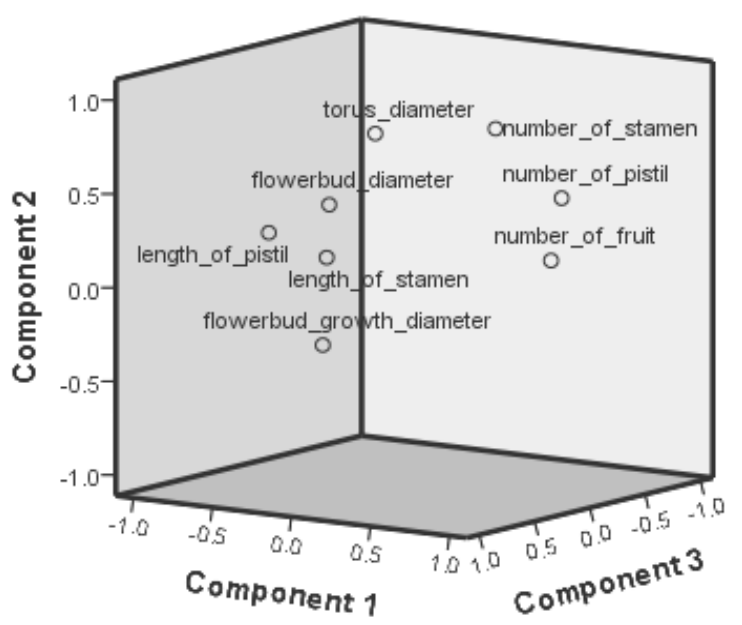

Figure 3. The component plot in rotate space by PCA

Furthermore, Table 3 gives information about the stamen and pistil's characteristics (length and color). The longest stamen and pistil, namely Blackberry $(5.59 \mathrm{~mm})$ and $R$. alceifolius $(7.32 \mathrm{~mm})$, respectively. The shortest stamen and pistil, namely $R$. lineatus and $R$. rosifolius with $1.35 \mathrm{~mm}$ and $1.81 \mathrm{~mm}$ in length, respectively.

The highest mean of flower bud diameters $(5.83 \mathrm{~mm})$ was found in $R$. alceifolius, followed by Blackberry with $5.81 \mathrm{~mm}$ in widths (Table 4). The $R$. pyrifolius has the smallest flower bud, with $3.51 \mathrm{~mm}$ in diameters. Variations of the floral form of the nine species of Rubus are also shown in the torus character. Rubus alceifolius, $R$. moluccanus, and $R$. pyrifolius have an umbrella-shaped torus; $R$. chrysophyllus and $R$. ellipticus are triangular, and $R$. fraxinifolius, $R$. rosifolius, and Rubus sp (Blackberry) have similar torus form, namely bulge. On the other hand, the torus of $R$. linneatus is parallel. Additionally, petal and sepal colors among the nine species look similar in that most petals are greyish yellow-green, while sepals' colors are moderate to intense yellow-green.

The flower morphology characters of Rubus were investigated by PCA (Principal Component Analysis).
Table 5 and Figure 3 explain that the PCA examinated divided into PC1, PC 2, and PC 3, which a total variance of $76.091 \%$. The PC1 alone was $37.254 \%$, and PC 2 was $20.728 \%$. When Eigenvalue (the length of a principal component that measures the principal component's variance) was examined in Table 5, they were 2.980 in $\mathrm{PC} 1,1.658$ in PC2, and 1.449 in PC3. The PC1 was found to be associated with the number of pistils, the number of fruits, length of the pistil, and length of a stamen; PC2 was found to be the number of stamens, flower bud diameter, and torus diameter; and PC3 was found to be flower bud diameter and flower bud growth diameter.

\section{Discussion}

The morphological characteristics of all Rubus species reported in this study are similar and relatively consistent with those described by Kalkman (1993) and Graham and Woodhead (2011). Kalkman (1993) described the Rubus species as hermaphrodites, wherein elaborated thyrsoid with whole ovate sepal formed by five imbricated pieces. Moreover, Graham and Woodhead (2011) reported that Rubus flowers are pentamer flowers with small, white to pink petals, many stamens, and an apocarpous gynoecium of many carpels, a cone-like receptacle. Recent PCA phenetic analysis represents that similar flower forms of Rubus did not indicate they in the same clades (Real and Madulid 2019); instead, the homoplasy of flower forms may be correlated with pollination agents (Van der Niet et al. 2014; Souto-Vilarós et al. 2018). On the other hand, the separation of the structure of reproductive organs from their function is practically impossible because of its associated functionally and indivisible (Dafni 1992).

The development of racemose flower in Rubus not concurrent but alternating; one flower and the others in the raceme have a range of $1-10$ days. The onset and duration of stages in the flower development affected by endogenously sources used in the flowering process and strongly influenced by the climatic condition under which the plants were growing (Donders et al. 2014; Hatfield and Prueger 2015; Hodnefjell et al. 2018).

Nine species of Rubus of CBG collection used in this study divided into two subgenera are Ideobatus and Malachobatus. The species included subgenera Ideobatus, namely $R$. ellipticus, $R$. fraxinifolius, $R$. rosifolius, and Blackberry. On the other hand, $R$. alceifolius, $R$. chrysophyllus, $R$. lineatus, $R$. moluccanus, and $R$. pyrifolius include subgenera Malachobatus. The characteristics of the subgenera Ideobatus and Malachobatus were showed in the length of stamen and pistils. The length of the stamen of $R$. alceifolius, $R$. chrysophyllus, $R$. lineatus, and $R$. moluccanus (subgenera of Malachobatus) were longer than their pistils and have elevated torus shape. In otherwise, $R$. ellipticus, $R$. fraxinifolius, $R$. rosifolius, and Rubus $\mathrm{sp}$ (Blackberry) (subgenera Ideobatus) have the stamens shorter than the pistils and a more varied torus shape from elevated to flat (Zandee and Kalkman 1981).

The different lengths of pistil and stamen might indicate the divergence of pollination behavior for each species. Jiang et al. (2010) and Kuester et al. (2017) reported that a field investigation validated the stamen-pistil ratio showing 
their outcrossing levels of the breeding system. The higher stamen-pistil ratio indicated they a nearly obligate outcrossing species; on the opposite, the getting lower of the stamen-pistil ratio indicates that they are facultative autogamous species. The positive correlation between stamen-pistil and pistil-fruit described that pistils have a significant role in pollination. The average percentage of natural pollinated-fruitfulness of each species was different. Pawar et al. (2017) reported that the selfpollination in $R$. ellipticus resulted in the highest percentage of fruit set $(96.66 \%)$, followed by natural pollination (76.66\%). Hiregoudar et al. (2019a) observed that the initial fruit set percentage of natural pollination was $68.75 \%$ in $R$. paniculatus.

Hiregoudar et al. (2019a,b) reported that the appearance of stigma turned to a thoroughly creamy color on the day of anthesis indicates the highest amount of sugary secretion and fresh display. The pollination conducted at this stage led to the highest fruit set. The styles became completely straight and showed peak receptivity. Further analysis of stigma receptivity and morphological change may lead to visible associations between stigma receptivity and flower development stages that could be employed in controlled pollination methods in Rubus.

A fundamental comprehension of flower structure, sexuality, and phenology is essential for understanding the floral life cycle needed for any pollination study (Dafni 1992; Feijo et al. 2012). Flower morphology shows the pollination mechanisms of Rubus and determines the most pollinator visits often. Likewise, investigation of the fertility behavior of internal verticils (androecium and gynoecium) allows the designing of improvement for breeding programs of the species (López et al. 2019). Our study shows that the variety in the floral morphology of Rubus would straightly impact the diversity of flower characters for pollination knowledge and breeding systems. On the other hand, information on Rubus spp pollination systems is critical to enhancement breeding programs with controlled pollination.

In conclusion, the nine species of Indonesian Rubus have a specific character of floral morphology. The flower characteristics variation shows on the pistil, stamens, torus shape, and duration of flowering stages between species. Flower development duration takes ranging 10-12 days from initiation to anthesis. Furthermore, a positive correlation was presented between the number of stamens and pistil and between the number of pistils and fruits. The variety in Rubus' floral morphology would directly impact flower characteristics' diversity for pollination knowledge and breeding systems.

\section{ACKNOWLEDGEMENTS}

The authors are thanks to the Cibodas Botanical Gardens LIPI, Cianjur-Indonesia. This study was supported by the University of Indonesia through PUTI Saintekes 2020 project (NKB-2391/UN2.RST/HKP.05.00/2020).

\section{REFERENCES}

Alice LA, Campbel CS. 1999. Phylogeny of Rubus (Rosaceae) based on nuclear ribosomal DNA internal transcribed spacer region sequences. Am J Bot 86 (1): 81-97. DOI: 10.2307/2656957

Dafni A. 1992. Pollination Ecology: A Practical Approach. Oxford University Press, New York.

Donders TH, Hagemans K, Dekker SC, de Weger LA, de Klerk P, Wagner-Cremer F. 2014. Region-specific sensitivity of anemophilous pollen deposition to temperature and precipitation. PLoS ONE 9 (8): e104774. DOI: 10.1371/journal.pone.0104774.

Endress PK. 2010. The evolution of floral biology in basal angiosperms. Philos Trans R Soc B Bio Sci 365 (1539): 411-421. DOI: 10.1098/rstb.2009.0228.

Feijo JA, Certal AC, Boavida L, Van Nerum E, Valdiviesso T, Oliveira MM, Broothaerts W. 2012. Advance on the study of sexual reproduction in the Cork-Tree (Quercus suber L.), Chesnut (Castanea sativa Mill.) and in Rosaceae (Apple and Almond). In: Cresti M, Cai G, Moscatelli A (eds) Fertilization in Higher Plants: Molecular and Cytological Aspects. Springer, Berlin.

Focke WO. 1910. Species ruborum: monographiae generis rubi prodromus. E. Schweizerbart.

Frankel R, Galun E. 2012. Pollination Mechanisms, Reproduction and Plant Breeding. Vol. 2. Springer Science \& Business Media, New York.

Graham J, Woodhead M. 2011. Rubus. Wild Crop Relatives: Genomic and Breeding Resources. Springer, Berlin.

Hatfield JL, Prueger JH. 2015. Temperature extremes: Effect on plant growth and development. Weather Clim Extrem 10 (A): 4-10. DOI: 10.1016/j.wace.2015.08.001.

Heide OM, Sønsteby A. 2011. Physiology of flowering and dormancy regulation in annual- and biennial-fruiting red raspberry (Rubus Idaeus L.) - A Review. J Hort Sci Biotechnol 86 (5): 433-442. DOI: 10.1080/14620316.2011.11512785.

Hiregoudar H, Manju, Negi P, Bundela MK. 2019a. Studies on pollen quality and quantity, stigma receptivity, pollination, and fruit set in raspberry (Rubus Paniculatus S.) wild species of Garhwal Himalaya, Uttarakhand, India. Intl J Chem Stud 7 (1): 2211-2216.

Hiregoudar H, Manju, Deepika, Nautiyal BP. 2019b. Floral biology of wild raspberry (Rubus macilentus C.) species of Garhwal Himalaya, Uttarakhand, India. Intl J Chem Stud 7 (1): 2200-2206. E-ISSN: 2321-4902

Hodnefjell R, Heide OM, Rivero R, Remberg SF, Sønsteby A. 2018. Control of growth cessation and floral initiation in red raspberry (Rubus Idaeus L.) cultivars of diverse origin in controlled and natural environments. Sci Hortic 233: 412-420. DOI: 10.1016/j.scienta.2018.02.011.

Jiang N, Yu WB, Li HZ, Guan KY. 2010. Floral traits, pollination ecology, and breeding system of three clematis species (Ranunculaceae) in Yunnan Province, Southwestern China. Aust J Bot 58 (2): 115-123. DOI: 10.1071/BT09163.

Kalkman C. 1993. Rosaceae. Flora Malesiana-Series 1. Spermatophyta 11 (2): 227-351.

Kuester A, Fall E, Chang SM, Baucom RS. 2017. Shifts in outcrossing rates and changes to floral traits are associated with the evolution of herbicide resistance in the common morning glory. Ecol Lett 20 (1): 41-49. DOI: 10.1111/ele.12703.

Lechowicz K, Wrońska-Pilarek D, Bocianowski J, Maliński T. 2020. Pollen morphology of polish species from the genus Rubus 1 . (Rosaceae) and its systematic importance. PLOS ONE 15 (5): e0221607. DOI: 10.1371/journal.pone.0221607.

López GAM, Ángel MLM, López LMG, Sánchez CFB. 2019. Rubus Glaucus Benth.: morphology and floral biology aimed at plant breeding processes. Rev Fac Nac Agron Medellin 72 (3): 8909-8915. DOI: 10.15446/rfnam.v72n1.75910.

Lu L, Wortley AH, Li D, Wang H, Blackmore S. 2015. Evolution of angiosperm pollen. 2. The basal angiosperms. Ann Missouri Bot Gard 100 (3): 227-269.

Moreno-Medina BL, Casierra-Posada F, Cutler J. 2018. Phytochemical composition and potential use of Rubus species. Gesunde Pflanz 70 (2): 56-74. DOI: 10.1007/s10343-018-0416-1.

Nielsen A, Reitan T, Rinvoll AW, Brysting AK. 2017. Effects of competition and climate on a crop pollinator community. Agric Ecosyst Environ 246: 253-260. DOI: 10.1016/j.agee.2017.06.006. 
Pawar N, Thakur N, Negi M, Paliwal A. 2017. Studies on pollen germination, pollination and fruit set in raspberry (Rubus Ellipticus) under Hilly Conditions of Uttarakhand. Int J Curr Microbiol Appl Sci 6 (9): 3698-3703. DOI: 10.20546/ijcmas.2017.609.456.

Peng DL, Ou XK, Xu Bo, Zhang ZQ, Niu Y, Li ZM, Sun H. 2014. Plan sexual systems correlated with morphological traits: reflecting reproductive strategies of alpine plants. J Syst Evol 52 (3): 368-377. DOI: $10.1111 /$ jse.12046.

Ramírez-Barahona S, Sauquet H, Magallón S. 2020. The delayed and geographically heterogeneous diversification of flowering plant families. Nat Ecol Evol 4 (9): 1232-1238. DOI: 10.1038/s41559-0201241-3.

Real MSB, Madulid DA. 2019. A phenetic analysis of Philippine Rubus species (Rosaceae) by morphology. Philippine J Syst Biol 13 (1):8596. DOI:10.26757/pjsb2019a13009

Redmond CM, Stout JC. 2018. Breeding system and pollination ecology of a potentially invasive alien Clematis vitalba L. in Ireland. J Plant Ecol 11 (1): 56-63. DOI: 10.1093/jpe/rtw137.

Setyawan AD. 1999. Distribution and abundance of Rubus in Mount Lawu. BioSMART 1 (2): 34-41. [Indonesian]

Sedgley M, Griffin AR. 2013. Sexual Reproduction of Tree Crops Academic Press, New York.

Sochor M, Trávníček B, Király G. 2019. Ploidy level variation in the genus Rubus in the Pannonian Basin and the Northern Balkans, and evolutionary implications. Plant Syst Evol 305 (8): 611-626. DOI: 10.1007/s00606-019-01593-3.

Souto-Vilarós D, Vuleta A, Jovanović SM, Budečević S, Wang H, Sapir Y, Imbert E. 2018. Are pollinators the agents of selection on flower colour and size in irises?. Oikos 127 (6): 834-846. DOI: 10.1111/oik.04501.

Susandarini R. 2016. Keragaman Rubus di gunung kembang kabupaten Wonosobo Jawa Tengah dan potensi pemanfaatannya. J Trop Biodivers Biotechnol 1 (1): 9. DOI: 10.22146/jtbb.12928.

Williams IH. 1959. Effects of environment on Rubus idaeus L. flower initiation and development of the inflorescence. J Hort Sci 34 (4): 219-228. DOI: 10.1080/00221589.1959.11513962.

Williams JH. 2012. Pollen tube growth rates and the diversification of flowering plant reproductive cycles. Intl J Plant Sci 173 (6): 649-661. DOI: $10.1086 / 665822$.

Van der Niet T, Peakall R, Johnson SD. 2014. Pollinator-driven ecological speciation in plants: new evidence and future perspectives. Ann Bot 113 (2): 199-212. DOI: $10.1093 / \mathrm{aob} / \mathrm{mct} 290$.

Yang JY, Lee W, Kim SC, Pak JH. 2015. The taxonomic entity and distribution of Rubus palmatus var. palmatus and R. palmatus var. coptophyllus (Rosaceae) in Korea. Korean J Plant Taxon 45 (3): 221 226. DOI: 10.11110/kjpt.2015.45.3.221.

Zandee M, Kalkman C. 1981. The genus Rubus (Rosaceae) in Malesia: I. subgenera Chamaebatus and Idaeobatus. Blumea 27 (1): 75-113. 